\title{
SARS-CoV-2 Viral Load Assessment in Lung Transplantation
}

\author{
Rene NOVYSEDLAK ${ }^{1}$, Jiri VACHTENHEIM Jr. ${ }^{1}$, Ilja STRIZ ${ }^{2}$, Ondrej VIKLICKY ${ }^{3}$, Robert \\ LISCHKE $^{1}$, Zuzana STRIZOVA ${ }^{4}$
}

${ }^{1}$ Third Department of Surgery, Prague Lung Transplant Program, First Faculty of Medicine, Charles University and University Hospital Motol, Prague, Czech Republic, ${ }^{2}$ Department of Immunology, Institute for Clinical and Experimental Medicine, Prague, Czech Republic, ${ }^{3}$ Department of Nephrology, Transplant Centre, Institute for Clinical and Experimental Medicine, Prague, Czech Republic, ${ }^{4}$ Department of Immunology, Second Faculty of Medicine, Charles University and University Hospital Motol, Prague, Czech Republic

Received July 14, 2021

Accepted August 26, 2021

\section{Summary}

In the era of COVID-19 pandemic, organ transplantation programs were facing serious challenges. The lung transplantation donor pool was extremely limited and SARS-CoV-2 viral load assessment has become a crucial part of selecting an optimal organ donor. Since COVID-19 is a respiratory disease, the viral load is thought to be more important in lung transplantations as compared to other solid organ transplantations. We present two challenging cases of potential lung donors with a questionable COVID-19 status. Based on these cases, we suggest that the cycle threshold (Ct) value should always be requested from the laboratory and the decision whether to proceed with transplantation should be made upon complex evaluation of diverse criteria, including the nasopharyngeal swab and bronchoalveolar lavage PCR results, the Ct value, imaging findings and the medical history. However, as the presence of viral RNA does not ensure infectivity, it is still to be clarified which $\mathrm{Ct}$ values are associated with the viral viability. Anti-SARS-CoV-2 IgA antibodies may support the diagnosis and moreover, novel methods, such as quantifying SARS-CoV-2 nucleocapsid antigen in serum may provide important answers in organ transplantations and donor selections.

\section{Key words}

COVID-19 • Lung transplantation • Organ donor • PCR • Cycle threshold

\section{Corresponding author}

Z. Strizova, Department of Immunology, Second Faculty of Medicine, Charles University and University Hospital Motol, V Uvalu 84, 15006 Praha 5, Czech Republic. E-mail: zuzana.strizova@fnmotol.cz

Coronavirus disease 2019 (COVID-19) pandemic has become one of the greatest challenges in the recent history (Lacina et al. 2021, Hubacek et al. 2021, Paces et al. 2020). The disease outbreak has impacted the entire society with one of the most influenced area being the healthcare (Huang et al. 2021).

Due to an extremely high transmissibility and a high mortality of COVID-19, especially among immunocompromised patients, both diagnostic and therapeutic processes have significantly changed (Paces et al. 2020, Patt et al. 2020, Sica et al. 2021, Khairallah et al. 2021, Vasku 2020). In order to manage this unprecedented situation, intensive care units, as well as standard hospital wards and ambulatory care practices, were accordingly reshaped to provide the best protection against COVID-19 transmission and to allow gaining a control over the COVID-19 (Dzupova et al. 2021, Baccolini et al. 2021).

Nonetheless, while the management of the COVID-19 dominated the diagnostic and therapeutic landscape in most European countries, other medical areas were negatively altered (Patt et al. 2020, Sica et al. 
2021, Khairallah et al. 2021, Dzupova et al. 2021, Allam et al. 2020).

In the era of COVID-19 pandemic, organ transplantation programs faced serious challenges (Azzi et al. 2021, Esagian et al. 2020, DeFilippis et al. 2020). The lung transplantation donor pool was extremely limited and novel guidelines for the management of organ donors and recipients had to be created (Azzi et al. 2021, Keller et al. 2020).

The COVID-19 mortality among transplant recipients was found to be substantially high and thus, a great effort is still being made to search for SARS-CoV-2 in both organ donors and recipients (Lieberman et al. 2020). Currently, all potential organ recipients on the transplant waiting list are advised to undergo vaccination against the COVID-19 and are screened for the COVID-19 infection prior to transplantation (Scharringa et al. 2021). Vaccination against the COVID-19 is also recommended in organ recipients after the transplantation despite the fact that several studies already indicated the impairment of the anti-SARS-CoV-2 specific immunity in solid organ transplant recipients (Shostak et al. 2021, Havlin et al. 2021). In fact, mRNA vaccines were found to elicit only limited antibody responses in lung transplant recipients but contrarily, displayed a capacity to promote the induction of anti-SARS-CoV-2 reactive T cells (Shostak et al. 2021, Havlin et al. 2021).

Still, there are many issues that accompany the SARS-CoV-2 viral load assessment in organ donors. For instance, various studies already reported cases of unclear COVID-19 status in individuals that required a highly personalized and careful evaluation of their infectivity based on multiple criteria (Lieberman et al. 2020, Oran et al. 2021, Messika et al. 2021, Amor et al. 2021, Rao et al. 2020, Theodore et al. 2021, Miller et al. 2021, Fisher et al. 2021).

In this report, we present two challenging cases of potential lung donors with a questionable COVID-19 status, Figure 1.

\section{ORGAN TRANSPLANTATION}
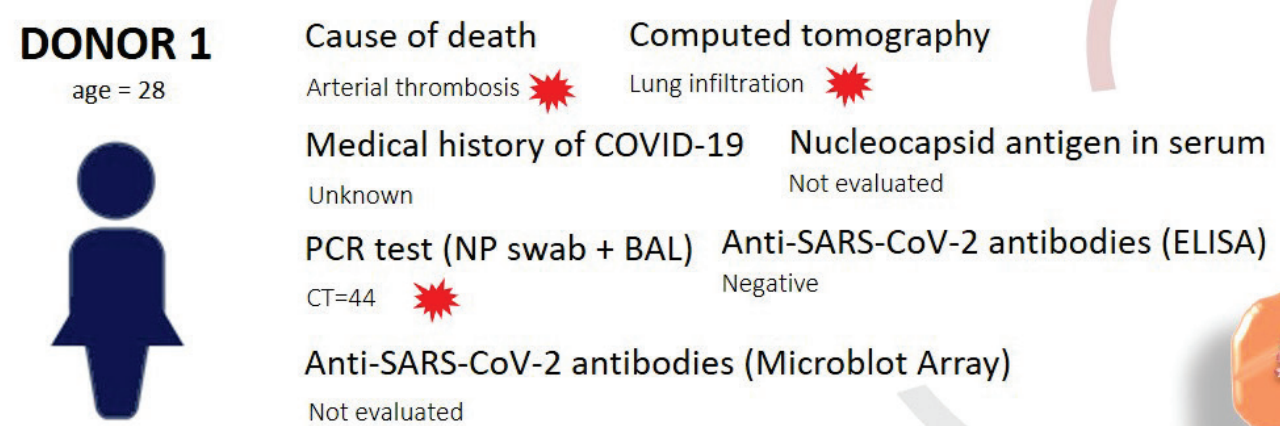

DONOR 2

age $=58$

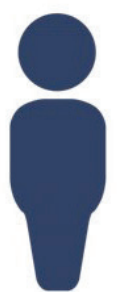

Cause of death

craniotrauma

\section{Computed tomography}

Lung infiltration

Medical history of COVID-19 Nucleocapsid antigen in serum COVID-19 disease 3 weeks prior to death Not evaluated

$\begin{array}{ll}\text { PCR test (NP swab + BAL) } & \text { Anti-SARS-CoV-2 antibodies (ELISA) } \\ \text { CT }=39.4 & \text { Negative }\end{array}$

Anti-SARS-CoV-2 antibodies (Microblot Array)

Positive IgA against Nucleocapsid $(248.97 \mathrm{U} / \mathrm{ml})$

Positive IgG against Nucleocapsid $(672.66 \mathrm{U} / \mathrm{ml})$

Positive IgG against S1 subunit of S protein (RBD region), (223.89 $\mathrm{U} / \mathrm{ml}$ )

Fig. 1. Two donors and relevant factors associated with the clinical decision-making in relation to SARS-CoV-2 viral load and organ transplantation. Red marks label the factors that served as the exclusion criteria for lung transplantation. 
The first donor was a young 28-years old female that died due to a thrombosis of basilar artery. This donor was presented as SARS-CoV-2 PCR positive at the primary Institution but came out PCR negative one day later at another Institution. Her organs were being considered for transplantation.

According to the generally accepted recommendations, bronchoalveolar lavage (BAL) should be examined in patients with suspected COVID-19 infection after a negative nasopharyngeal (NP) swab (Theodore et al. 2021, Gao et al. 2021). In our case, two consecutive PCR tests performed on BAL were negative, as well as the anti-SARS-CoV-2 antibodies that were retrospectively examined. To assess the level of positivity of the first PCR, we have requested the cycle threshold (Ct) count from the primary Institution. The $\mathrm{Ct}$ was 44 and, in most cases, $\mathrm{Ct}$ above 40 is considered negative (Falasca et al. 2020). Nevertheless, PCR assays are highly sensitive and allow a detection of an extremely low viral load (Oran et al. 2021, Messika et al. 2021). Therefore, in the process of decision-making whether to transplant, this became an issue. Also, the computed tomography $(C T)$ revealed non-specific lung infiltration that could imply viral affection. Based on these findings, the lungs were not transplanted while the heart, the liver and the kidney transplantations were performed.

The second case was a 58-years-old male who died due to a craniotrauma that had a recent medical history of COVID-19 disease. This donor was tested SARS-CoV-2 PCR positive with the Ct 38 two days before the admission and the $\mathrm{Ct} 39.4$ at the day of the planned transplantation. To obtain more data, we have retrospectively examined the antibodies by a microblotarray and found positive IgG against the $R B D$ region and against the nucleocapsid, and positive $\operatorname{IgA}$ against the nucleocapsid $(248.9 \mathrm{U} / \mathrm{ml})$. CT revealed pleural effusion with associated lung parenchyma abnormalities and thus, the lung transplantation was not carried out.

SARS-CoV-2 viral load assessment is a crucial part of selecting an optimal organ donor (Lieberman et al. 2020). Since COVID-19 is a respiratory disease, the viral load may be more important in lung transplantations as compared to other solid organ transplantations (Messika et al. 2021). General criteria for accepting/declining lungs remain controversial and to date, there is still a significant proportion of possible donor lungs that are declined due to parenchyma abnormalities, such as pulmonary arterial thrombosis, pulmonary infarction, bronchopneumonia, and other findings (Verleden et al. 2017).
CT examination was proposed as a simple and valuable tool to decide whether to accept or decline donor lungs. Yet, there is no evidence that lungs with CT alterations could not be transplanted (Verleden et al. 2017).

In the era of COVID-19, accepting or declining donor organs for transplantations has become extremely challenging and especially the quality of lung allografts has raised serious concerns (Azzi et al. 2021, Keller et al. 2020).

While the COVID-19 pandemic has led to an increase of patients dying while on transplant waiting list, the risk of severe illness and death from COVID-19 in transplant recipients seems to outweigh the risk of donor organ shortage (Miller et al. 2021, Fisher et al. 2021).

PCR testing allow prompt and accurate detection of SARS-CoV-2, however, the information about the positivity/negativity alone may not be sufficiently sensitive to discriminate acceptable and nonacceptable lungs (Lanser et al. 2021).

Based on our previous experiences, we suggest that in unclear cases, the $\mathrm{Ct}$ value should always be requested and the decision should be made upon complex evaluation of diverse criteria, including the NP swab and BAL PCR results, the $\mathrm{Ct}$ value, imaging findings and medical history, Figure 2. To note, it is still to be clarified which $\mathrm{Ct}$ values are associated with the viral viability. Anti-SARS-CoV-2 IgA antibodies may support the diagnosis and moreover, novel methods, such as quantifying SARS-CoV-2 nucleocapsid antigen in the serum may provide important answers in organ transplantations and donor selections (Ogata et al. 2020).

\section{Conflict of Interest}

There is no conflict of interest.

\section{Acknowledgements}

The study was not supported by external funding.

\section{Abbreviations}

BAL - bronchoalveolar lavage, COVID-19 - coronavirus disease 2019, CT - computed tomography, Ct - cycle threshold, Ig - immunoglobulin, NP - nasopharyngeal, PCR - polymerase chain reaction, RBD - receptor binding domain, RNA - ribonucleic acid, SARS-CoV-2 severe acute respiratory syndrome coronavirus 2 , SOT solid organ transplant. 


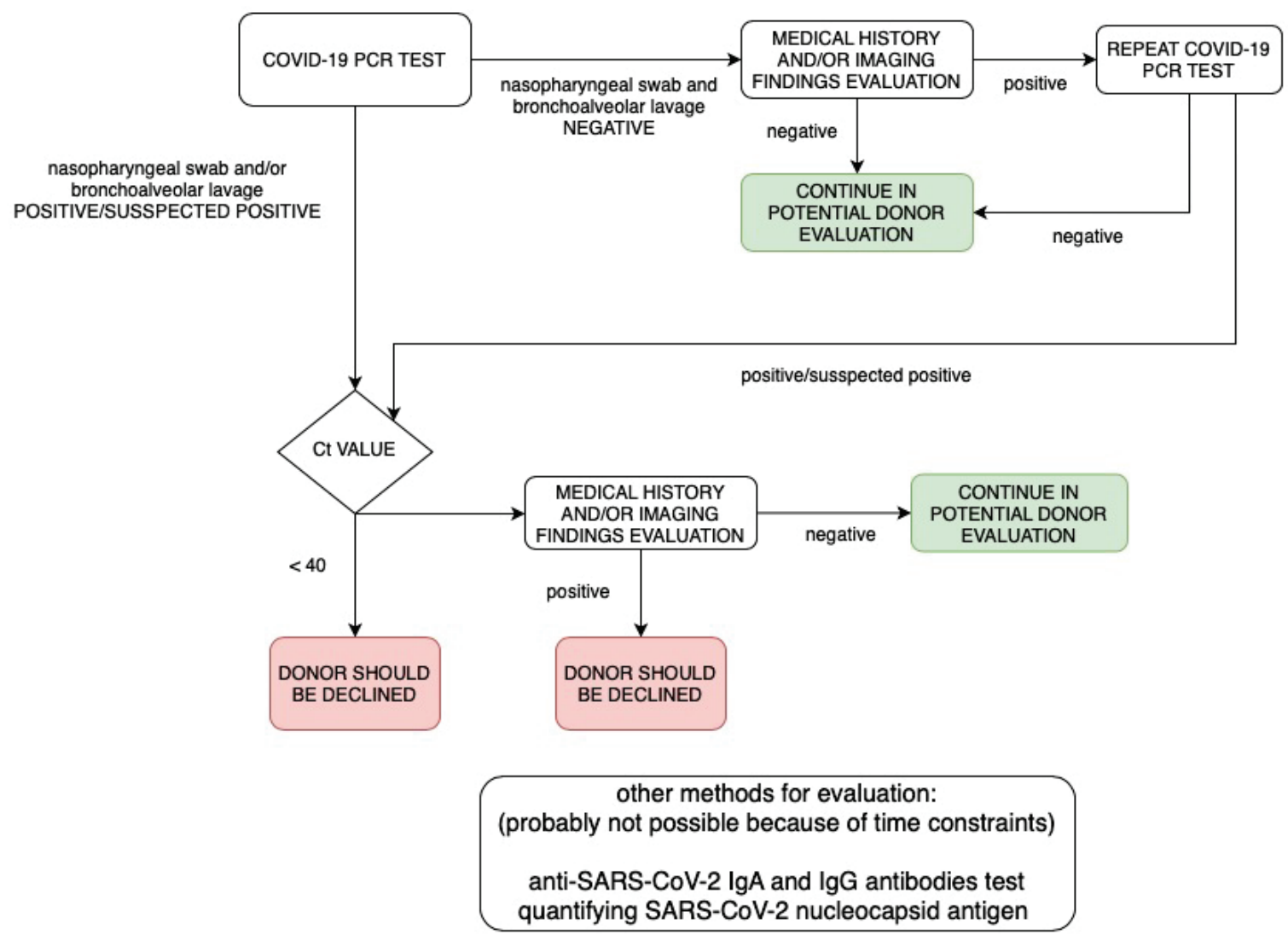

Fig. 2. Diagnostic algorithm for the evaluation of COVID-19 status in organ donor in lung transplantation.

\section{References}

ALLAM MF, ANDRAOUS F: Use of chloroquine or hydroxychloroquine in treatment of COVID-19: Is it ethical? Cent Eur J Public Health 28: 246-247, 2020. https://doi.org/10.21101/cejph.a6464

AMOR SM, FOX BD, GRUBSTEIN A, ROSENGARDEN D, SHOSTAK Y, SHITENBERG D, KRAMER MR: Poor outcomes of COVID-19 in lung transplant recipients. Cohort study in a single center. J Heart Lung Transpl 40 (Supplement): S144, 2021. https://doi.org/10.1016/j.healun.2021.01.442

AZZI Y, BARTASH R, SCALEA J, LOARTE-CAMPOS P, AKALIN E: COVID-19 and solid organ transplantation: A review article. Transplantation 105: 37-55, 2021. https://doi.org/10.1097/TP.0000000000003523

BACCOLINI V, MIGLIARA G, ISONNE C, DORELLI B, BARONE LC, GIANNINI D, MAROTTA D, MARTE M, MAZZALAI E, ALESSANDRI F, PUGLIESE F, CECCARELli G, DE VITO C, MARZUILLO C, DE GIUSTI M, VILLARI P: The impact of the COVID-19 pandemic on healthcare-associated infections in intensive care unit patients: a retrospective cohort study. Antimicrob Resist Infect Control 10: 87, 2021. https://doi.org/10.1186/s13756021-00959-y

DEFILIPPIS EM, FARR MA, GIVERTZ MM: Challenges in heart transplantation in the era of COVID-19. Circulation 141: 2048-2051, 2020. https://doi.org/10.1161/CIRCULATIONAHA.120.047096

DZUPOVA O, MORAVEC M, BARTOS H, BRESTOVANSKY P, TENCER T, HYÁNEK T, BEROUSEK J, KRUPKOVA Z, MOSNA F, VYMAZAL T, BENES J: COVID-19 severe pneumonia: Prospective multicentre study on demands on intensive care capacities. Cent Eur J Public Health 29: 3-8, 2021. https://doi.org/10.21101/cejph.a6672

ESAGIAN SM, ZIOGAS IA, GIANNIS D, HAYAT MH, ELIAS N, TSOULFAS G: Challenges in abdominal organ transplantation during the COVID-19 pandemic. Front Med (Lausanne) 7: 287, 2020. https://doi.org/10.3389/fmed.2020.00287 
FALASCA F, SCIANDRA I, Di CARLO D, GENTILE M, DEALES A, ANTONELLI G, TURRIZIANI O: Detection of SARS-COV N2 Gene: Very low amounts of viral RNA or false positive? J Clin Virol 133: 104660, 2020. https://doi.org/10.1016/j.jcv.2020.104660

FISHER AM, SCHLAUCH D, MULLOY M, DAO A, REYAD AI, CORRELL M, FROMELL GJ, PITTMAN J, BINGAMAN AW, SANKARAPANDIAN B, ALLAM SR: Outcomes of COVID-19 in hospitalized solid organ transplant recipients compared to a matched cohort of non-transplant patients at a national healthcare system in the United States. Clin Transplant 35: e14216, 2021. https://doi.org/10.1111/ctr.1421

GAO CA, CUTTICA MJ, MALSIN ES, ARGENTO AC, WUNDERINK RG, SMITH SB; NU COVID Investigators: Comparing Nasopharyngeal and BAL SARS-CoV-2 Assays in Respiratory Failure. Am J Respir Crit Care Med 203: 127-129, 2021. https://doi.org/10.1164/rccm.202008-3137LE

HAVLIN J, SVORCOVA M, DVORACKOVA E, LASTOVICKA J, LISCHKE R, KALINA T, HUBACEK P: Immunogenicity of BNT162b2 mRNA COVID-19 vaccine and SARS-CoV-2 infection in lung transplant recipients. J Heart Lung Transplant 40: 754-758, 2021. https://doi.org/10.1016/j.healun.2021.05.004

HUANG F, ARMANDO M, DUFAU S, FLOREA O, BROUQUI P, BOUDJEMA S: COVID-19 outbreak and healthcare worker behavioural change toward hand hygiene practices. J Hosp Infect 111: 27-34, 2021. https://doi.org/10.1016/j.jhin.2021.03.004

HUBACEK JA, DUSEK L, MAJEK O, ADAMEK V, CERVINKOVA T, DLOUHA D, PAVEL J, ADAMKOVA V: CCR5Delta32 deletion as a protective factor in Czech first-wave COVID-19 subjects. Physiol Res 70: 111-115, 2021. https://doi.org/10.33549/physiolres.934647

KELLER BC, LE A, SOBHANIE M, CULBURN N, BURCHAM P, ROSENHECK J, HOWSARE M, GANAPATHI AM, ATYIA SA, HADEN M, WHITSON BA, MOKADAM NA, NUNLEY DR: Early COVID-19 infection after lung transplantation. Am J Transplant. 20: 2923-2927, 2020. https://doi.org/10.1111/ajt.16097

KHAIRALLAH P, AGGARWAL N, AWAN AA, VANGALA C, AIRY M, PAN JS, MURTHY BVR, WINKELMAYER WC, RAMANATHAN V: The impact of COVID-19 on kidney transplantation and the kidney transplant recipient - One year into the pandemic. Transpl Int 34: 612-621, 2021. https://doi.org/10.1111/tri.13840

LACINA L, BRABEK J, FINGERHUTOVA S, ZEMAN J, SMETANA K JR: Pediatric Inflammatory Multisystem Syndrome (PIMS) - Potential role for cytokines such is IL-6. Physiol Res 70: 153-159, 2021. https://doi.org/10.33549/physiolres.934673

LANSER L, BELLMANN-WEILER R, ÖTTL KW, HUBER L, GRIESMACHER A, THEURL I, WEISS G: Evaluating the clinical utility and sensitivity of SARS-CoV-2 antigen testing in relation to RT-PCR Ct values. Infection 49: 555-557, 2021. https://doi.org/10.1007/s15010-020-01542-0

LIEBERMAN JA, MAYS JA, WELLA C, CENT A, BELL D, BANKSON DD, GRENINGER AL, JEROME KR, LIMAYE AP: Expedited SARS-CoV-2 screening of donors and recipients supports continued solid organ transplantation. Am J Transplant 20: 3106-3112, 2020. https://doi.org/10.1111/ajt.16081

MESSIKA J, ELOY P, ROUX A, HIRSCHI S, NIEVES A, LE PAVEC J, SENECHAL A, SAINT RAYMOND C, CARLIER N, DEMANT X, LE BORGNE A, TISSOT A, DEBRAY MP, BEAUMONT L, RENAUDPICARD B, REYNAUD-GAUBERT M, MORNX JF, FALQUE L, BOUSSAUD V, JOUGON J, MUSSOT S, MAL H, FRENCH GROUP OF LUNG TRANSPLANTATION: COVID-19 in lung transplant recipients. Transplantation 105: 177-186, 2021. https://doi.org/10.1097/TP.0000000000003508

MILLER J, WEY A, MUSGROVE D, SON AHN Y, HART A, KASISKE BL, HIROSE R, ISRANI AK, SNYDER JJ: Mortality among solid organ waitlist candidates during COVID-19 in the United States. Am J Transplant 21: 2262-2268, 2021. https://doi.org/10.1111/ajt.16550

OGATA AF, MALEY AM, WU C, GILBOA T, NORMAN M, LAZAROVITS R, MAO CP, NEWTON G, CHANG M, NGUYEN K, KAMKAEW M, ZHU Q, GIBSON TE, RYAN ET, CHARLES RC, MARASCO WA, WALT DR: Ultra-sensitive serial profiling of SARS-CoV-2 antigens and antibodies in plasma to understand disease progression in COVID-19 patients with severe disease. Clin Chem 66: 1562-1572, 2020. https://doi.org/10.1093/clinchem/hvaa213

ORAN DP, TOPOL EJ: The proportion of SARS-CoV-2 infections that are asymptomatic: A systematic review. Ann Intern Med 174: 655-662, 2021. https://doi.org/10.7326/M20-6976 
PACES J, STRIZOVA Z, SMRZ D, CERNY J: COVID-19 and the immune system. Physiol Res 69: 379-388, 2020. https://doi.org/10.33549/physiolres.934492

PATT D, GORDAN L, DIAZ M, OKON T, GRADY L, HARMISON M, MARKWARD N, SULLIVAN M, PENG J, ZHOU A: Impact of COVID-19 on cancer care: How the pandemic is delaying cancer diagnosis and treatment for american seniors. JCO Clin Cancer Inform 4: 1059-1071, 2020. https://doi.org/10.1200/CCI.20.00134

RAO SN, MANISSERO D, STEELE VR, PAREJA J: A systematic review of the clinical utility of cycle threshold values in the context of COVID-19 [published correction appears in Infect Dis Ther 2020 Aug 18]. Infect Dis Ther 9: 573-586, 2020. https://doi.org/10.1007/s40121-020-00324-3

SCHARRINGA S, HOFFMAN T, VAN KESSEL DA, RIJKERS GT: Vaccination and their importance for lung transplant recipients in a COVID-19 world. Expert Rev Clin Pharmacol 10: 1-13, 2021. https://doi.org/10.1080/17512433.2021.1961577

SHOSTAK Y, SHAFRAN N, HECHING M, ROSENGARTEN D, SHTRAICHMAN O, SHITENBERG D, AMOR SM, YAHAV D, BEN ZVI H, PERTZOV B, KRAMER MR: Early humoral response among lung transplant recipients vaccinated with BNT162b2 vaccine. Lancet Respir Med 9: e52-e53, 2021. https://doi.org/10.1016/S2213-2600(21)00184-3

SiCA A, SAgNelli C, CASAle B, SVANERA G, CRETA M, CALOGERO A, FRANCO R, SAGNELli E, RONCHI A: How fear of COVID-19 can affect treatment choices for anaplastic large cell lymphomas ALK+ therapy: A case report. Healthcare (Basel) 9: 135, 2021. https://doi.org/10.3390/healthcare9020135

THEODORE DA, GREENDYKE WG, MIKO B, WHITTIER S, GREEN DA, SHOUCRI S, VERNA EC, ZUCKER J, SOBIESZCZYK ME, AARON JG, SCULLY BE, SAIMAN L, PEREIRA M, FURUYA EY: Cycle thresholds among solid organ transplant recipients testing positive for SARS-CoV-2. Transplantation 105: 1445-1448, 2021. https://doi.org/10.1097/TP.0000000000003695

VASKU A: Covid-19 infection and the host genetic predisposition: does it exist? Physiol Res 69: 511-514, 2020. https://doi.org/10.33549/physiolres.934504

VERLEDEN SE, MARTENS A, ORDIES S, HEIGL T, BELLON H, VANDERMEULEN E, VAN HERCK A, SACREAS A, VERSCHAKELEN J, COUDYZER W, VAN RAEMDONCK DE, VOS R, WEYNAND B, VERLEDEN GM, VANAUDENAERDE B, NEYRINCK A: Radiological analysis of unused donor lungs: A tool to improve donor acceptance for transplantation? Am J Transplant 17: 1912-1921, 2017. https://doi.org/10.1111/ajt.14255 